\title{
The First Amendment and Minority Rights
}

\author{
Tom C. Clark†
}

George Mason, one of my favorites among the founders of our country, echoed the problem of the ages when he said that the "dangers of the majority oppressing the minority and the mischievous influence of demagogues" is the chief evil of government. We shall direct our attention to this ever-recurring evil.

In the early days of Grecian, Roman, and English civilizations, sovereign power was a two-edged sword. It held at bay innumerable marauders who preyed upon weaker members of the community. At the same time, it often turned its own fury upon those it protected. Still those injured were wont to bear their yoke rather than make an outright attack upon their protector and, failing, lose his favor. But as tyrannous acts became more burdensome, the subjects or classes sought to set some limit upon their abuses. Magna Carta might well afford an example. In short, although the ruler was a necessary evil-harboring conflicting interests and antagonistic attitudes-the subjects dared not destroy him.

Gaining more courage, subjects later found it to their advantage to exercise power themselves through elected agents or representatives. The old ruler became merely a symbol of the authority which was actually vested in the people's representatives. Through such an arrangement, they reasoned, the real ruler was of and from the people and their interests were identical; the need for any limitation on the exercise of power was, therefore, no longer present, for the people needed no protection against themselves. The notion appeared foolproof but it soon proved itself fallacious. The will of the people-expressed through their representatives-was the rule of the majority. Soon oppression returned, this time being visited upon the minority. Instead of the tyranny of the king, it was simply the tyranny of the majority. Tyranny's circle was complete. The colonists found the same tyranny that they sought to escape. They had learned, as Madison so

\footnotetext{
$\uparrow$ Former Associate Justice of the United States Supreme Court, 1946-67. This address was delivered by Mr. Justice Clark as the Sixth Annual Meiklejohn Lecture at Brown University, April 19, 1968.
} 
well expressed it, that "to secure the public good and private rights against the danger of ... faction, and at the same time to preserve the spirit and the form of popular government"1 had long been the great interest of man on earth.

Thomas Jefferson was one of the first of the founders to put to writing a formula on civil rights. It was simple, direct, and short. It was included in the Statute for Religious Liberty introduced in the Virginia Assembly in 1784 and adopted in 1785. It admonished all Virginians that:

to suffer the civil magistrate to intrude his powers into the field of opinion, and to restrain the profession or propagation of principles on supposition of their ill tendency, is a dangerous fallacy, which at once destroys all religious liberty ... ; that it is time enough for the rightful purpose of civil government to interfere when principles break out into overt acts against peace and good order.

However, a half dozen years later, Madison outdistanced Jefferson by placing in the Constitution the Bill of Rights, the first ten amendments. In them is included the entire coterie of civil right protections. We shall consider the one to which Madison gave preference, the first amendment. It contains but 45 words, exactly nineteen less than Jefferson's earlier effort, providing that:

Congress shall make no law respecting an establishment of religion or prohibiting the free exercise thereof; or abridging the freedom of speech, or of the press; or the right of the people to peaceably assemble and to petition the government for a redress of grievances.

There is little legislative history as to the amendment. In the Constitutional Convention it was given scant, if any, attention. It was in the course of ratification that the absence of a Bill of Rights was used as a weapon against its adoption. It was at this time that Madison proposed that amendments be later adopted that would

expressly declare the great rights of mankind secured under this Constitution ... the great object in view is to limit and qualify the powers of Government by excepting out of the grant of power those cases in which the Government ought not to act, or to act only in a particular mode. ${ }^{2}$

1 The Federalist No. 10, at 132 (B. Wright ed. 1961) (J. Madison).

21 AnNals of Cong. 432 (1789). 
At that time, some of the states suggested amendments, including provisions against any infringement of religion, conscience or of the press. Madison, who proposed the amendments, commented during their presentation only as to the infringement of religion and conscience clauses. Mr. Egbert Benson made this general statement on the report of the committee proposing the amendments:

The Committee who framed this report proceeded on the principle that these rights belonged to the people; they conceived them to be inherent; and all that they meant to provide against was their being infringed by the Government. ${ }^{3}$

There was little interpretation of the amendment by the courts. A national awareness of its meaning was first exhibited in the Sedition Act of 1798. The Act was condemned by both Madison and Jefferson as being unconstitutional; the General Assembly of Virginia resolved against "the palpable and alarming infractions of the Constitution" included in it; and Congress itself repaid all the fines levied under its prosecutions on the ground that it was unconstitutional. Perhaps the paucity of cases reaching the Court during the early period of the amendment is accounted for by this experience. However, in 1833, Chief Justice Marshall recognized in Barron $v$. Baltimore $e^{4}$ that:

the great revolution which established the Constitution of the United States was not effected without immense opposition. Serious fears were extensively entertained that those powers which the patriot statesmen ... deemed essential to the union ... might be exercised in a manner dangerous to liberty. ... . [The] amendments demanded security against the apprehended encroachments of the general governmentnot against those of the local governments.

The necessity for the Bill of Rights is illustrated by the distinction between the original Constitution and the first amendment. Article I of the former declares that "all legislative power herein granted shall be vested in a Congress," while the first amendment opens with the prohibition that "Congress shall make no law."

At this point we might as well set to rest some theories to which I do not subscribe. First of all, I do not believe that the first amendment's commands are absolutes. The Court has refused to so hold. Again and again it has said that "the freedom of speech which is se-

3 Id. 759.

4 32. U.S. 180, 185, 7 Pet. 243, 250 (1833). 
cured by the Constitution does not confer an absolute right."5 I submit that the Constitution is not a suicide pact; the preservation of the government that it creates is its paramount concern and all individual rights are subservient to the necessity of its self-preservation. In reading the amendment, I do not stop with the reading of the opening phrase: "Congress shall make no law." I proceed to read the remainder of the language used by the framers in its true context.

Nor do I believe that the framers intended for the Constitution to be interpreted solely in the light of its history and the debates surrounding its adoption-nor for that matter to follow the literal, narrow meaning of its words. If that were true, the segregation opinions could have never been written. The Court, rather than searching for historical meanings, concluded "we cannot turn the clock back to 1868 when the [Fourteenth] Amendment was adopted, or even to 1896 when Plessy v. Ferguson was written."6 As Chief Justice Hughes had earlier said:

If by the statement that what the Constitution meant at the time of its adoption it means to-day, it is intended to say that the great clauses of the Constitution must be confined to the interpretation which the framers, with the conditions and outlook of their time, would have placed upon them, the statement carries its own refutation. ${ }^{7}$

Moreover, I do not subscribe to the conclusion that "Freedom of press, freedom of speech, [and] freedom of religion are in a preferred position" in the constitutional constellation, ${ }^{8}$ if that language means that these are "preferred freedoms." It may be that, since they are included in an amendment numbered "First," their numerical position is preferred. But I cannot say that such numerical order-whether placed there by Madison or a legislative clerk-gives those rights preferred treatment over all others in the Constitution and its amendments. While, as Mr. Justice Reed said in Murdock v. Pennsylvania, "none of the provisions of our Constitution is more venerated," I cannot say that it is preferred. What of the right to counsel, to a jury trial in a criminal case, to protection against self-incrimination and against unreasonable searches and seizures? These, too, are noble requirements which we honor as being fundamental concepts of liberty which are

5 Whitney v. California, 274 U.S. 357, 371 (1927). See also Cox v. New Hampshire, 312 U.S. 569, 574, 576 (1941); Cantwell v. Connecticut, 310 U.S. 296, 303 (1940).

6 Brown v. Board of Education, 347 U.S. 483, 492 (1954).

7 Home Building and Loan Ass'n. v. Blaisdell, 290 U.S. 398, 442-3 (1934).

8 Murdock v. Pennsylvania, 319 U.S. 105, 115 (1943).

9 Id. 121 (dissent). 
embraced by the fourteenth amendment. In this connection I should say here that, in my view, the Bill of Rights was not incorporated in toto into the due process clause of the fourteenth amendment and through it applied to the states. One by one, certain provisions of the Bill of Rights, including the first amendment, have been declared to be among the fundamental rights and liberties protected by the fourteenth amendment from impairment by the states.

What is my first amendment philosophy? It might be stated in the general terms of John Stuart Mill in his essay, "On Liberty," where he first posed the questions: "What, then, is the rightful limit to the sovereignty of the individual over himself? Where does the authority of society begin? How much of human life should be assigned to individuality, and how much to society?" 10 And after pointing out that the "proper share" to which each is due has been the enigma of the ages, Mill says:

every one who receives the protection of society owes a return for the benefit, and the fact of living in society renders it indispensable that each should be bound to observe a certain line of conduct towards the rest ... first, in not injuring the interests of one another; or rather certain interests, which, either by express legal provision, or by tacit understanding, ought to be considered as rights; and secondly, in each person's bearing his share (to be fixed on some equitable principle) of the labours and sacrifices incurred for defending the society or its members from injury and molestation. ${ }^{11}$

But, "when a person's conduct affects the interests of no persons besides himself," Mill reasoned, "there should be perfect freedom, legal and social, to do the action and stand the consequences."12 However, there are "many positive acts ... . which he may rightfully be compelled to perform; such as to give evidence in a court of justice; and to bear his fair share in the common defense."13 And I might add that in wartime the Government must have more elbow room. The Court, during the crisis of war, has never yet seen fit to challenge governmental power in any vital area. The extent of its willingness is shown by the Japanese exclusion cases during World War II. ${ }^{14}$ Having

$10 \mathrm{~J}$. S. MILL, On Liberty, in UTILTARIANISM, LIBERTY AND REPRESENTATTVE GOVERNMENT 176 (1951).

11 Id. 177.

$12 \mathrm{Id}$.

13 Id. 97.

14 Korematsu v. United States, 323 U.S. 214 (1944); Hirabayashi v. United States, 320 U.S. 81 (1943). 
served as the Civilian Coordinator of the Western Defense Command at its inception, I know well of its impact. I agree with Chief Justice Hughes that the power to wage war includes the power to wage it successfully.

This brings us to the specifics. It is fitting that we first address ourselves to freedom of speech which in my view is a paramount right of all Americans.

It was 129 years after the Court was organized that it first began to grapple with the first amendment's prohibition against the abridgement of freedom of speech. The Court had been preoccupied with property rights under the due process clause; human rights were cast to one side. It is reminiscent of the slogan of Bob Young of the C. \& O. Railroad: A hog can cross the country without changing trains, but a human being cannot.

In Schenck v. United States ${ }^{15} \mathrm{Mr}$. Justice Holmes enunciated the celebrated clear and present danger test as an aid to decision in determining when words sufficiently approached deeds so as to throw the peril of their use upon the speaker. The case is perhaps the better known because Justice Holmes, in illustrating his thesis, employed one of his most unforgettable aphorisms-that the "most stringent protection of free speech would not protect a man in falsely shouting fire in a theater and causing a panic."16 The Court has often applied the clear and present danger test, especially in the subversive activities and obstruction of justice fields. While some commentators have taken stabs at the test, the resulting wounds have been superficial. Dennis $v$. United States ${ }^{17}$ construed the test to mean that where the preservation of society itself is at stake the threat to its existence might not necessarily have to be immediate but could be remote. Even in the latest subversive case, Yates $v$. United States, ${ }^{18}$ the Court gave the test recognition but found it unnecessary to apply it. The Court ruled that a speaker may be prosecuted when he goes beyond abstract discussion and advocates some overt act designed to overthrow the Government by force or violence. Some of the Justices did not agree. They held that one cannot be convicted "simply for agreeing to talk as distinguished from agreeing to act." They would permit "talking about public affairs, whether or not such discussion incites to action, legal or illegal."19 In short, they say free speech "can be suppressed if, and to the extent

15294 U.S. 47 (1919).

16 Id. 52.

17341 U.S. 494 (1951).

18354 U.S. 298 (1957).

19 Id. 340 . 
that, it is so closely brigaded with illegal action as to be an inseparable part of it." ${ }^{120}$ I must add that this latter theory has not yet been accepted by the Court. Another test that has evolved in recent years is tagged as "the balancing test." In short, the decision-maker weighs the right claimed against the necessities of the state. The test has been applied in such cases as Sweezy v. New Hampshire, ${ }^{21}$ Scales v. United States, ${ }^{22}$ Cantwell v. Connecticut, ${ }^{23}$ Feiner v. New York, ${ }^{24}$ and others. In short, it is accurate to say that the first amendment assures the broadest possible exercise of free speech. The amendment grew out of an experience which taught that a society cannot trust the majority to keep its zeal within the limits that a free society can tolerate. This is not to say that one can use fighting words or excitations to violence.

Even those who give absolute protection to free speech draw a line between speech and conduct. In situations where people are speaking in places where they have no right to be the power of restriction is present. Trespass seems to be the criterion. For example, the right to picket, demonstrate, or march is not absolute where it is done on the streets, in government-owned buildings, or on private property without consent. Such action, they say, is not speech and is not protected. Persons so engaged are not only communicating ideas but pursuing a course of conduct in addition. As Justice Douglas pointed out in Bakery Drivers Local v. Wohl, picketing is more than speech since it involves patrol of an area and may induce action..$^{25}$ Indeed, the Court has held that the first amendment presents no bar to the adoption of laws regulating, controlling, or even prohibiting such a course even though speaking, singing, or signs accompany it. Giboney $v$. Empire Storage of $I c e^{26}$ is a case in point. Since it is made up of speech and conduct, a demonstration or march may be regulated and often is. It marks the distinction between seeking orderly changes in governing rules and defying law through civil disobedience. The difference between belief and action is clearly pointed up in polygamous marriage. A Mormon tenet expresses belief in plural marriages for men. Society itself views such action as sinful. When Mormons were prosecuted for violating a federal law prohibiting polygamy, they claimed that their religious faith was protected under the first amendment; but their claim was rejected on the ground that the church, by giving illegal

\footnotetext{
21354 U.S. 234 (1957).

22367 U.S. 203 (1961).

23310 U.S. 296 (1940).

24340 U.S. 315 (1951).

25315 U.S. 769, 776 (1942) (dissenting).

26396 U.S. 490 (1949).
}

20 Roth v. United States, 354 U.S. 476, 514 (1957). 
conduct religious approval, had lost its constitutional protection. Speech has no constitutional freedom where it is an integral part of conduct in violation of law. Thornhill $v$. Alabama ${ }^{27}$ struck down Alabama's anti-picketing law not on first amendment principles but on vagueness and breadth.

Picketing and marching by their nature infringe simply because they use other people's property. The question arises, must government provide a place for such activity? The better rule is that it need not. The first amendment gives protection to speech and assembly, but it says nothing about supplying a place to carry on such activity. Perhaps an office to receive grievances is required but propagandizing on the streets is more than petitioning the government. In my view the government does not have to provide buildings, parks, streets, etc., for such purposes. However, if it permits such use to one group it must provide it for all who come in orderly fashion. Government is not permitted to pick and choose among the views it is willing to have discussed on its streets, in its parks, or in its buildings. It is well to remember that laws governing conduct are subject to scrutiny if they indirectly have an impact upon ideas. But speech is not free in all places, at all times, or in every manner. When it menaces peace and order there comes a point beyond which one cannot indulge in provocation to violence. The heavy responsibility to keep this point true rests upon the local officials in the first instance, but ultimately upon the courts. Freedom of speech exists because of law, not despite it. As Chief Justice Stone has said, "Government has a right to survive" -indeed, that is its duty, and powers conferred upon it are not necessarily set at naught by the express provisions of the first amendment. It may compel citizens to give military service in its protection-and this despite conscientious objection; it may suppress religious practices dangerous to morals; it may force attendance in schools; it may control streets and public property; it may take blood though it be for prosecutions for drunk driving; it may protect its own existence from riots and insurrections. Free speech is but the guarantee of freedom of the human mind and spirit, and of reasonable freedom and opportunity to express it. As Mr. Justice Black said in Cox v. Louisiana, ${ }^{28}$

Minority groups in particular need always to bear in mind that the Constitution, while it requires States to treat all citizens equally and protect them in the exercise of rights granted by the Federal Constitution and laws, does not take

27310 U.S. 88 (1940).

28379 U.S. 559, 584 (1965). 
away the State's power, indeed its duty, to keep order and to do justice according to law. Those who encourage minority groups to believe that the United States Constitution and federal laws give them a right to patrol and picket in the streets whenever they choose, in order to advance what they think to be a just and noble end, do no service to those minority groups, their cause, or their country. I am confident from this record that this appellant violated the Louisiana statute because of a mistaken belief that he and his followers had a constitutional right to do so, because of what they believed were just grievances. But the history of the past 25 years if it shows nothing else shows that his group's constitutional rights have to be protected by the courts, which must be kept free from intimidation and coercive pressures of any kind. Government under law as ordained by our Constitution is too precious, too sacred, to be jeopardized by subjecting the courts to intimidatory practices that have been fatal to individual liberty and minority rights wherever and whenever such practices have been allowed to poison the streams of justice. I would be wholly unwilling to join in moving this country a single step in that direction.

Another facet of free speech is the exchange of ideas through association. Effective advocacy is enhanced by group association. American Communications Association v. Douds, ${ }^{29}$ you will remember, held that regulation might discourage the exercise of constitutional rights. The regulation there was upheld because, on balance, it was found that the necessity for the act was constitutionally sufficient to justify the deterrent. This was likewise true in some congressional investigation cases, such as United States v. Rumely. ${ }^{30}$ But in NAACP v. Ala$b a m a^{31}$ the state failed to show a controlling justification for the deterrent effect on the enjoyment of the right to associate which disclosure of membership lists was likely to have.

Symbolism is also an expression of speech. The flag salute cases are in point-West Virginia School Board $\%$. Barnette ${ }^{32}$ set straight that proposition. As Mr. Justice Stone, later the Chief Justice, said in dissent in Minersville $v$. Gobitis, ${ }^{33}$ which Barnette overruled, the essence of liberty is the freedom of the individual from compulsion as to what he shall think. The first amendment withholds from the State

\footnotetext{
29339 U.S. 382 (1950).

80345 U.S. 41 (1953).

31357 U.S. 449 (1958).

32319 U.S. 629 (1943).

33310 U.S. 586 (1940).
} 
any authority to compel belief or expression of it where that expression violates conviction. There have been few infringements of personal liberty that have not been justified in the name of right and public good, and most of them have been aimed at helpless minorities. The first amendment is a command that freedom of mind and spirit must be maintained.

As Mr. Justice Cardozo said so well,

personal liberty is a poor and shrunken thing, incapable of satisfying our aspirations or our wants, if it does not exact as its minimal requirement that there shall be the maintenance of opportunity for the growth of personality. ${ }^{34}$

Indeed, Chief Justice Hughes, writing in Stromberg v. California, ${ }^{35}$ upheld the display of a red flag as a symbol of opposition to government.

There is a final area that I wish to mention. It has to do with the first amendment and conscience. It has to do presently with the draft. The basic argument is that some laws are just and some are unjust; that each person may determine for himself, in accordance with his own conscience, in which category each law falls; that even though such laws are held valid the disobedient may continue his recalcitrance if his conscience will not permit him to submit.

The philosophical justification for this doctrine finds a higher law than that of man. It is the conscience of the individual. Its foundation is the unjust law that is out of step with morality. The test of enforceability is the individual's conscience. It employs a Gertrude Stein logic: A conscience is a conscience is a conscience.

I encounter great difficulty with this doctrine. First it leaves to a person's conscience the choice of what law is immoral; it leaves with his conscience the determination of whether it will be enforced; it leaves with his conscience the final decision. In short, it reflects, as Mr. Justice Stewart said in Walker v. Birmingham, ${ }^{36}$ a belief that in the fair administration of justice a man can be judge of his own case. That is not true regardless of the man's exalted position in life, however righteous his motives and irrespective of his race, color, or religion.

In a society as complex as ours such a rule could lead only to anarchy. One man's conscience is another man's poison. There would be no law, no order, and soon, no society. Our society is structured on the principle of voluntary compliance with law. To foster, aid, and abet

34 B. Gardozo, The Paradoxes of Legal Science 103-4 (1928).

35283 U.S. 359 (1931).

36388 U.S. 307 (1967). 
disobedience would lead only to mob rule and, as Abraham Lincoln said in his Lyceum Club speech in 1828, to despotism. The policy of integration illustrates where the conscience doctrine leads. Thousands upon thousands of people believe that the segregated life is not only morally right but that it is the better for them and the country. It was the backbone of the doctrine of interposition that once blossomed in the South. It sparked the program of massive resistance to the effort to integrate the public schools. No person adhered more firmly to that doctrine than Governor Barnett. He said that his conscience told him that integration was unjust. His duty as governor was therefore clearhe must disobey the order of a federal court. He disobeyed, he lost. From a legal standpoint why is Governor Barnett's case any different than that of the draft disobedient?

We live in a period of great unrest and discord. The ultimate danger of civil disobedience is to the rule of law and the framework of government which sustains it. Those who adopted the first amendment were faced with similar problems-the whisky raids and Dorr's rebellion right here in Rhode Island. They often wondered whether America was rising or setting in the world firmament of nations. Madison's report of the final minutes of the Constitutional Convention points up the problem. It reads:

Whilst the last members were signing [the Constitution] Dr. Franklin [who at that time was 81 years old and was nearing the end of a glorious career] looking towards the Presidents Chair, at the back of which a rising sun happened to be painted, observed to a few members near him, that Painters had found it difficult to distinguish in their art, a rising from a setting sun. I have said he, often and often in the course of the Session, and the vicissitudes of my hopes and fears as to its issue, looked at that behind the President without being able to tell whether it was rising or setting: But now at length I have the happiness to know that it is a rising and not a setting Sun. ${ }^{37}$

And now more than 180 years later we know that Benjamin Franklin was a prophet. America has risen to the heights. But there is much more to be done. We too are faced with seemingly insurmountable tasks. But all things are surmountable by those who resolve to devote their lives-as did the framers-to the cause. Let we who sit here in this historic spot so resolve-to follow the example and teaching of those who fashioned the Bill of Rights. I have faith that we will.

37 J. Madison, Notes of Debates in the Federal Convention of 1787, at 659 (1966). 